\title{
EBAY LAW: THE LEGAL IMPLICATIONS OF THE C2C ELECTRONIC COMMERCE MODEL
}

\author{
Andrés Guadamuz González. \\ Lecturer, University of Edinburgh
}

Abstract

This paper attempts to address some of the legal implications of the popular Consumer-to-Consumer electronic commerce model, in particular the implications of the successful and popular auctions site eBay.

\section{Keywords}

Electronic commerce, consumer, C2C, eBay, intermediary liability, internet auctions, contract, fraud, unfair terms, online dispute resolution.

\section{Introduction}

Much has been written about the Business-to-Business (B2B) and Business-toConsumer (B2C) models of electronic commerce, but there is a surprisingly small amount of information about the legal implications of the Consumer-to-Consumer model $(\mathrm{C} 2 \mathrm{C})$, which is the system of e-commerce that serves as a facilitator in a transaction between individuals or small enterprises. The lack of literature in this area is made more evident by the fact that the $\mathrm{C} 2 \mathrm{C}$ model is proving to be one of the most successful developments in electronic commerce after the dot.com bubble burst and the internet business scene changed completely.

One of the best examples of this model can be found in the shape of various internet auctions websites, of which the site eBay is the strongest example. The success of this company cannot be understated, boasting a vast number of transactions taking place daily and an ever growing number of users. However, with the growing number of online transactions between consumers, legal conflicts are likely to occur, hence the importance of understanding some of the legal implications of the $\mathrm{C} 2 \mathrm{C}$ model and whether or not existing legislation is adequately prepared for the challenges posed by this new commercial environment.

The present paper will analyse the auction model by taking a look at some of the legal issues involved, such as the contractual implications, the liability (or lack of) of 
auction sites, and the online dispute resolution model used to solve conflicts between users.

\section{The eBay phenomenon}

The success of internet auction sites has usually been made synonymous with one of the most successful survivors from the dot.com era, eBay.

As with so many other stories of wildly innovative and successful enterprises, the tale of eBay begins with a very simple idea. French-born Pierre Omidyar designed the site in 1995 to help his fiancée purchase PEZ dispensers online. Omidyar had been looking for new applications for the nascent internet and he thought that having an auction site would be a good idea. He programmed a small site called AuctionWeb as a hobby; something he never thought would generate enough income to leave his daytime job. ${ }^{1}$ These pessimistic views were justified during the early days of the site, which was not generating many hits and did not have many customers. Omidyar recalls that he discovered that the model could be a success when he sold a broken laser pointer for fourteen dollars even after making sure that he stated that it did not work. ${ }^{2}$ The rest is history; AuctionWeb started receiving larger numbers of users, so many that Omidyar had to start charging a small percentage per finalised transaction to maintain the growing economic demands posed by the site. By early 1996 he had earned $\$ 1,000$, and the figures started doubling daily. By June, AuctionWeb was generating \$10,000 per month, and Omidyar had in his hands a dot.com success. ${ }^{3}$

By 1997, the site had acquired its present name and was being courted by several other e-commerce giants. With a major technological overhaul, the site continued growing at breakneck speed, and the amount of transactions was growing exponentially. At present time, eBay is the largest internet auction site in the world, with a total of nearly 55 million confirmed registered users and an average 1.7 million new users every month, and over one million auctions being held daily. ${ }^{4}$ By 2002 , it was thought that as many as 100,000 Americans were making their living off eBay. ${ }^{5}$ At the end of 2002, eBay announced that it had made a total of \$288.8 million USD

\footnotetext{
${ }^{1}$ Cohen, A. The Perfect Store: Inside eBay, Boston : Little, Brown \& Co; 2002, p.19

${ }^{2}$ Ibid, p.4.

${ }^{3}$ Bunnell, D. and Luecke, R. The eBay Phenomenon. New York : John Wiley, 2000, pp.25-60.

4 eBay. eBay Inc. Announces Third Quarter 2002 Financial Results, October 17, 2002. @: <http://www.shareholder.com/ebay/news/20021017-92686.htm >

${ }^{5}$ Cohen, op cit; p. 10 .
} 
net profit in the third quarter; the site had 160 million items listed during the quarter, with total sales worth $\$ 3.77$ billion USD. ${ }^{6}$

EBay exploits many of the most important characteristics that have made the internet so popular; it empowers users and provides the internet community with a place in which they can exchange goods and services with each other. The amazing success of the eBay model can be attributed to many different reasons, ranging from sheer luck to an astute business plan, but at the heart of the site's accomplishments lays two basic truths about the internet. One is that people need a place where to buy and sell directly online, and the second is the principle of peer-review and community enforceability.

The second-hand market was a dormant giant before eBay came along. It is thought that by 1995 this market was worth one billion USD, made up of auctions, garage sales, flea markets and classified ads. ${ }^{7}$ What the internet managed through eBay was to expand the number of people that could be reached to sell one's used items. The old adage "one man's junk is another man's treasure" has been proven by eBay, where everything that can be sold is indeed sold daily. To this basic capitalist marketplace one must add the strong sense of community. Users police each other by providing feedback about fulfilled or failed transactions, this lends credibility to the business model and allows eBay to maintain its considerable user base.

\section{Some legal issues}

\subsection{The dark side of auctions}

With the large amount of transactions performed each day, the potential for legal conflict increases as well - with four out of every ten buyers reporting that they have had some sort of problem with their transactions. ${ }^{8}$ Although eBay has several mechanisms in place to avoid misuse of the site and diminish the possibilities of fraud, this still takes place. For example, the National Fraud Information Center in the United States reported that half of all complaints received by its Internet Fraud Watch in 1998 involved auctions transactions, while the figure had reached an alarming 87\%

\footnotetext{
${ }^{6}$ eBay 2002, op cit.

${ }^{7}$ Cohen, op cit; p.27.

${ }^{8}$ Selis, P; Ramasastry, A. and Sato, A. Towards a Fraud-Free Marketplace: Best Practices for the Online Auction Industry. Report by the Washington Attorney General's Office, April 2001. @: <http://www.wa.gov/ago/consumer/auctions/home.htm>
} 
in 2002. ${ }^{9}$ In 2000, the Federal Trade Commission (FTC) received more than 25,000 complaints for web-based auction fraud, which increased from just 100 in $1997 .{ }^{10}$

The problem for eBay when it comes to fraudulent practices from and against its users is that it must attempt to achieve some balance between providing as much freedom for its users as possible, and the imposition of enough restrictions to safeguard them from fraud, which may drive some of them away. After all, eBay is a place that has made a reputation as an open marketplace for users.

It is with this in mind that the many stories of illegal or even tasteless items being placed for sale in the site have generated some undesired publicity for this business model. A common practice from some fraudulent users is to log with two different accounts, one as a seller and another one as a buyer. If an honest buyer bids for an item, the seller can log in with another account and bid on the item as well to increase the price. Several people have suffered from this practice, buying items at a price that has been dishonestly pushed up by unscrupulous sellers. ${ }^{11}$

Another documented case of misuse is the attack of identity thieves on eBay. Several fraudsters have been using stolen credit cards to purchase domain names with the word "ebay" on them. With these sites these scam artists attract eBay users and make themselves pass as an official eBay site, and then they request personal information from the user and steal the details for anything from further credit card fraud to performing bank withdrawals in the victim's name. ${ }^{12}$

The auction site has also suffered from the regular sale of illegal or restricted items. People have attempted to sell such things as body parts, pirated works of any kind, hallucinogenic drugs, weapons, Nazi memorabilia, countries and spam lists. ${ }^{13}$ Dubious items make it all the time into the listings, including sex, prayers, enchantments, miracles, islands and most recently debris from the space shuttle

9 National Consumers League. Online Auction Fraud Skyrocketing in 2002, August 2002, @: $<\mathrm{http} / / /$ www.nclnet.org/fraudweek2.htm>

${ }^{10}$ FTC. Internet Fraud. Statement by the FTC to the Subcommittee on Commerce, Trade and Consumer Protection, 2000. @: <http://www.ftc.gov/os/2001/05/internetfraudttmy.htm>

${ }^{11}$ Brunker, M. "Cautionary tales of two auctions", MSNBC, October 10, 2002. @:

<http://www.msnbc.com/news/818257.asp?0si\&cp1=1>

${ }^{12}$ Festa, P. “Identity thieves strike eBay”, CNET News, November 22, 2002. @: <http://news.com.com/2100-1017-

966835.html>

${ }^{13}$ Bunnell and Luecke, op cit; pp.142-147. 
Columbia. ${ }^{14}$ Many of these items have been black-listed by eBay and often pulled out before they are sold, but the negative impression about the site usually remains.

\subsection{Dispute resolution}

Because of the nature of the eBay marketplace, the potential for conflict in any transaction is higher in comparison to any other method of retail of new or used goods. Users go to the site, see a listing and purchase goods that they have never seen from a person they have never met, and then the seller must be sure that the payment will arrive at some point. Common eBay etiquette demands that the seller will ship the items only after the buyer has made payment through the various available methods - which include postal orders, cheques, escrow, cash, and credit card transactions through intermediary payment systems like PayPal. ${ }^{15}$ EBay's feedback system tries to make sure that users will leave feedback of the transaction, warning other users of potential troublesome clients, and praising good transactions as a reward. But what happens if something wrong takes place and the normal flow of a commercial transaction fails?

This is where the "Law of eBay" comes in. EBay has recognised that users need other options other than going to a court of law to settle their differences. ${ }^{16}$ In the early days of eBay, Omidyar used to serve as a mediator, but as the site grew he decided that he could not handle all of the complaints and created a feedback forum to allow users to police the site as a community. ${ }^{17}$ This effort paid off, but did not eliminate complaints entirely.

This is the main reason for the adoption by the company of the alternative dispute resolution (ADR) model. EBay's contract has an arbitration clause for conflicts arising between the user and the company. The clause states:

\footnotetext{
14 "Ebay shuts down Columbia auctions", The Register, February 3, 2003. @: <http://www.theregister.co.uk/content/6/29147.html>

${ }^{15} \mathrm{PayPal}$ can be found here: 〈http://www.paypal.com>

${ }^{16}$ Bunnell and Luecke, op cit; pp.61-62.

${ }^{17}$ Cohen, op cit; pp.26-27.
} 
"Disputes between you and eBay regarding our services may be reported to eBay Customer Support. We encourage you to report all disputes between users to your local law enforcement body. However, any controversy or claim arising out of or in connection with this Agreement may at our discretion be settled by binding arbitration by reference to an arbitration tribunal designated by eBay. You agree to be bound by the ruling arbitrator.",18

Interestingly, there is the recent case of Combe v. PayPal, ${ }^{19}$ which is a subsidiary of eBay, where the court found that the arbitration clause included in the PayPal user agreement was unconscionable (inherently unfair). This case was brought by several PayPal users that were alleging that PayPal had frozen funds in their accounts. PayPal defended the case by saying that this conflict should be taken to arbitration as the parts had signed up to the PayPal user agreement, which contains a similar arbitration clause to that described above. Although the case is mostly a "click-wrap" case, it is important to note that the court was willing to throw out an arbitration clause, which should serve as a warning for the similar clause contained in eBay's user agreement.

In case of conflicts between users, eBay recommends the use of the Online Dispute Resolution (ODR), an application of ADR rules in an online environment. ${ }^{20}$ EBay started using ODR back in 1999 with a pilot project in tandem with the Center for Information Technology and Dispute Resolution at the University of Massachusetts. ${ }^{21}$ According to some of the academics in charge of the project, one of the main challenges that they had was to try to determine whether ODR would be considered only an alternative to resolve disputes in eBay, or if the online community would consider it the primary tool for solving conflicts arising from commercial transactions in the auctions site. ${ }^{22}$ To increase the ease in the online process, the Center decided to use mediation with one mediator as the most viable and easy to use ADR method. In the short period that the pilot programme ran, the organisers received a total of 225 complaints; and of the processes which had a complete mediation process, 46 percent achieved a successful mediation. ${ }^{23}$ A total of 144 of the complaints were not completed because the parts reached an agreement between them outside of the

\footnotetext{
${ }^{18}$ EBay User Agreement, para.16.

${ }^{19}$ Craig Comb, et al. v. PayPal, Inc. Cases No. C-02-1227 and C-02-2777 JF (N.D. Cal., August 30, 2002).

${ }^{20}$ For more on this subject, see: Rule, C. Online dispute resolution for business: B2B, e-commerce, consumer, employment, insurance, and other commercial conflicts, San Francisco: Jossey-Bass, 2002.

${ }^{21}<$ http://www.umass.edu/dispute>

${ }^{22}$ Katsh, E; Rifkin, J; and Gaitenby, A. "E-Commerce, E-Disputes, and E-Dispute Resolution: In the Shadow of 'eBay Law"', Ohio State Journal on Dispute Resolution, Vol. 15:3, 200, p.706.

${ }^{23}$ Ibid, pp.710-712.
} 
process or because their dispute was not related to the subject matter. A small number of complaints (only thirty-seven) were not continued because one of the parts did not want to continue with the mediation procedure. It is interesting to note that the largest number of complaints came from eBay buyers, and the main reason for complaining was the lack of delivery of the purchased goods. ${ }^{24}$ The study conducted by the Center concluded that ODR could be a considerable advantageous tool in solving disputes arising from eBay transactions, as customers in an online environment look for speed in resolution as part of the nature of electronic commerce. The authors of the report conclude that eBay could be considered a jurisdiction on itself, and state that in the $\mathrm{C} 2 \mathrm{C}$ environment "the most relevant and powerful law probably was eBay's law and the power it exercised as a result of users agreeing to the terms and conditions for participation that eBay presents to them." 25

As a result of the positive experiences with ODR, eBay now recommends the use of a specific tool called Square Trade. ${ }^{26}$ This company provides ODR services for eBay customers, and they claim to have solved 200,000 disputes, using mostly mediation as the main tool. There is no way at present to corroborate these figures, and an interesting further area of study would be to analyse the success of ODR in solving $\mathrm{C} 2 \mathrm{C}$ disputes.

\subsection{Liability}

One of the main characteristics of $\mathrm{C} 2 \mathrm{C}$ sites is the fact that they work as facilitators and intermediaries, which is usually stated in their terms of use. For example, eBay UK states in their agreement that:

"eBay is not an auctioneer. Although, we are commonly referred to as an online auction web site, it is important to realise that we are not a traditional auctioneer. eBay acts as a venue which allows registered users to offer, sell, and buy just about anything, at any time, from anywhere, in a variety of formats including fixed price and auctionstyle. ${ }^{27}$

Because of this status as a facilitator, eBay can operate with a low liability threshold. They state that "we will not be liable for any economic losses (including, without

\footnotetext{
${ }^{24}$ Ibid.

${ }^{25}$ Ibid, p.731.

${ }^{26}<\mathrm{http} / / /$ www.squaretrade.com/>

${ }^{27}$ EBay User Agreement, para. 3.
} 
limitation, loss of revenues, profits, contracts, business or anticipated savings), any loss of goodwill or reputation, or any special, indirect or consequential damages (however arising, including negligence) arising out of or in connection with this Agreement." 28 Such limitations of liability are not accepted as valid in several jurisdictions, so it is important to analyse instances in which courts of law have dealt with this issue.

An interesting case in the United States where the issue of liability was discussed was Gentry v. eBay. ${ }^{29}$ The claimants in this case filed a class action suit against eBay alleging that they had purchased counterfeit or fake sports memorabilia from other users through eBay, and they argued that eBay was liable for the fake memorabilia advertised in the site. The plaintiffs argued that this liability arose from the false advertising in the item description provided by third parties, for not providing any sort of certificate of authenticity, ${ }^{30}$ and also by giving false information in the shape of the customer feedback rating. The court adequately ruled that eBay was not responsible for the goods advertised as they served as facilitators and not as sellers, and that the auction site did not guarantee that any of the goods sold were genuine, which was the role of the actual seller. ${ }^{31}$ The court also found that eBay was not required to issue certificates as it was not the one selling the items. Lastly, the court also dismissed the argument that eBay was responsible in any way for customer feedback rating, as these comments are performed by third parties based on satisfaction or dissatisfaction from previous buyers. The court goes back to another landmark case about intermediary liability, that of Zeran v. AOL, ${ }^{32}$ in which intermediary service providers were found to be immune from liability arising from information originating from third parties. As eBay was never the originator of any of the information provided by the sellers, it had to be immune from liability in this case and could not possibly be expected to know that the memorabilia was genuine or not. Gentry shows that eBay can rest assured in the fact that the courts are not willing to find them liable for fraudulent transactions conducted within the site, which follows the growing number of opinions

\footnotetext{
${ }^{28}$ EBay User Agreement, para.12.

${ }^{29}$ Gentry, et al. v. eBay Inc., Super Ct. No. GIC746980 (Cal. Crt. App., June 26, 2002)

${ }^{30}$ As required by California legislation in the shape of the Autographed Sports Memorabilia statute.

${ }^{31}$ Davis, C. "Court Dismisses Class Action Against eBay in Counterfeit Sports Memorabilia Case", Internet Law Journal, March 8 2001. @: <http://www.tilj.com/content/litigationheadline03080101.htm>

${ }^{32}$ Zeran v. America Online, Inc. (4th Cir. 1997) 129 F.3d 327 (Zeran), cert. den. (1998) 524 U.S. 937 [118 S.Ct. 2341, 141 L.Ed.2d 712].
} 
and legislation that is giving intermediary service providers exemption from liability in a wide variety of cases. ${ }^{33}$ Another way of thinking of eBay under the circumstances raised by Gentry is that of a newspaper that carries classified ads, it is almost laughable to believe that such medium would be found liable for erroneous information contained in personal ads.

\subsection{Unfairness of exclusion clause}

This brings up the interesting question of whether or not the limitation of liability clause cited above is in itself an unfair term as defined by the Unfair Contract Term Act 1977 (UCTA) and the Unfair Terms in Consumer Contracts Regulations 1999 (UTCCR). The 1977 Act specifies a list of terms that will be considered unfair generally exclusion, limitation and indemnity clauses - and therefore these terms will not be binding. EBay's User Agreement does not appear to be directly against some of the unfair clauses listed by the Act such as exclusion of liability for breach of contract (s.3.1) or indemnity (s.12).

The only question that may arise is whether the clause presented above would be an exclusion of liability for negligence as described in s.2(2) of the UCTA. Negligence in the context of the act must be understood as any breach in an obligation from an implied or express term arising from the failure to "take reasonable care or exercise reasonable skill in the performance of the contract." 34 As defined, negligence in the case of eBay could arise if it was believed that the auction site did not provide an adequate screening process to stop fraudulent transactions as some of the ones described above, which would arise from a lack of reasonable care in avoiding fraudsters. As the exclusion clause for eBay is exclusion for damages arising from negligence in the part of $\mathrm{eBay}^{35}$, this would be the only section of the UCTA that would apply to its user agreement, and would possibly be the main contentious clause in case a customer would like sue eBay for damages one way or another. In this light, the UCTA states that a clause that excludes liability for loss or damage by negligence

\footnotetext{
${ }^{33}$ Limitation of ISP liability is an ongoing phenomenon that can be seen in a wide range of issues, from defamation to copyright infringement. See: Sutter, G. Don't Shoot the Messenger? The Evolution of Liability for third Party Provided Content in the UK, 17th BILETA Annual Conference, Free University, Amsterdam, 2002. @: <http://www.bileta.ac.uk/02papers/sutter.html>

${ }^{34}$ UCTA, s.1(1).

${ }^{35}$ EBay User Agreement, para.12.
} 
will be considered unfair if the term satisfies the reasonableness test. ${ }^{36}$ It is possible to distinguish some general guidelines from the Schedule 2 of the UCTA when assessing reasonableness. These requirements will now be listed with an explanation on whether or not they apply to the eBay user agreement:

1. The bargaining strengths of the parties relative to each other: It is obvious that in this part eBay has the upper hand, as the customer has no bargaining power whatsoever. $^{37}$

2. The customer received an inducement to agree to the term: This does not apply to the eBay agreement, unless one considers as inducement the fact that failure to agree with the agreement will result in the customer not being able to participate in the auction process.

3. Whether the customer knew or ought reasonably to have known of the existence and extent of the term: This is less difficult to ascertain, as eBay's user agreement is located at the very bottom of the main webpage. Worse than that, when a customer is registering for the first time, the user will find that the agreement is not presented in the typical "click-wrap" 38 format, which would imply serious questions about the proper incorporation of the contractual terms. ${ }^{39}$ It could be assumed that eBay users do not know about the exclusion term in question.

4. Reasonableness of a term that excludes or restricts liability if some condition is not complied with: This does not apply to eBay's agreement.

5. Whether the goods were manufactured, processed or adapted to the special order of the customer: This would seem to be negative as eBay is an intermediary.

It is not entirely clear if eBay's exclusion clause would be considered unfair on these grounds, as it is markedly difficult to determine reasonableness in advance because the wording of s.11.1 is vague and not all of the guidelines in the Schedule 2 are met or fully apply to the user agreement. It is also difficult to view reasonableness in certain terms as the apparent contradiction in some of the landmark cases dealing with unfair terms appear to indicate. ${ }^{40}$ It is the author's opinion that at least some of the

\footnotetext{
${ }^{36}$ Reasonableness is defined by s.11(1) thus: "the term shall have been a fair and reasonable one to be included having regard to the circumstances which were, or ought reasonably to have been, known to or in the contemplation of the parties when the contract was made."

${ }^{37}$ On the other hand, if the parties posses equal bargaining strength, it will be more difficult to prove unfairness. See: SAM Business Systems Limited v Hedley \& Co. [2002] EWHC 2733.

38 For more on click-wrap agreements, see: Gatt, A. "Electronic Commerce - Click-wrap agreements: The enforceability of click-wrap agreements", Computer Law \& Security Report, Vol. 18, Issue 6, November 2002, pp.404-410.

39 There is already an American case in which Netscape was punished for not presenting the terms in a proper way. See: Specht v. Netscape Communications Corp., 2001 WL 755396, 150 F. Supp. 2d 585 (S.D.N.Y., July 5, 2001), aff'd. -- F.3d -- (2d Cir., Oct. 1, 2002).

40 Differing views as to how "reasonableness" is applied can be found in: Phillips Products Ltd v. Hyland and Hamstead Plant Hire Co Ltd [1987] 2 All ER 620; Smith v. Eric S Bush [1990] 1 AC 831; and Thomson v. Lothan Ltd [1987] 2 All ER 631.
} 
elements of the reasonableness test are met, hence the clause could be found to be unfair under some circumstances dealing with negligence on the part of eBay. However, it will be interesting to see if the courts will agree with this view if this clause is ever brought forward.

There is a better chance of exploring the possible unfairness of the liability clause with the UTCCR. This regulatory regime is much broader than the UCTA because the Act is circumscribed to a specific set of clauses, while the Regulations are not. The main concept in the regulations is the definition of what an unfair term will be. According to the Regulation:

"A contractual term which has not been individually negotiated shall be regarded as unfair if, contrary to the requirement of good faith, it causes a significant imbalance in the parties' rights and obligations arising under the contract, to the detriment of the consumer."

A term will be considered to not have been negotiated individually if it has been drafted in advance and the consumer did not have a say in the terms of the final contract. $^{42}$ This definition is at the heart of any contractual dispute that may arise by the application of this Regulation. The UTCCR establishes test for unfairness in that the consumer must prove that there has been bad faith on the part of the undertaking, that there is a significant imbalance to the parties and that such imbalance must be detrimental to the consumer. As presented, the test is centred on the concept of good faith, and the definition of good faith in this context proves problematic because it has been imported to the UK via an EU Directive, and as such it may be understood according to Civil Law principles, which include a wide variety of considerations such as the gravity of the imbalance between the parts, the social position of the parties and the way in which the term in question came into existence. ${ }^{43}$

Nevertheless, the concept of good faith is not alien to British courts, and it has been recently analysed by Director General of Fair Trading v. First National Bank plc. ${ }^{44}$ In this case, the HL was asked to examine the validity of a contractual clause for financial transactions between a bank and consumers. When analysing good faith,

\footnotetext{
${ }^{41}$ UTCCR, s.5(1).

${ }^{42}$ UTCCR, s.5(2).

${ }^{43}$ Some of these principles can be seen in several continental cases, such as Saladin/HBU, Hoge Raad, NJ 1967.261 (G.J. Scholten). For a more complete work on the subject of good faith in Civil Law, see: Zimmermann, R. and Whittaker S. (eds) Good faith in European contract law, Cambridge: Cambridge University Press, 2000.

${ }^{44}$ Director General of Fair Trading v First National Bank Plc, [2001] UKHL 52; [2002] 1 A.C. 481.
} 
Lord Bingham specified that it had to be considered as containing fair and open dealing. Openness means that the term must be clear, legible and not contain hidden pitfalls; and fair dealing would have to be understood that the supplier should not take advantage of the other party's relatively weak position. Analysed in that light, it would be interesting to ascertain how the eBay clauses compare. The terms are clear enough and do not appear to contain any hidden traps, but it is difficult to determine fair dealing. It can be said that there is certainly an imbalance in the obligations of the parts, and they may be detrimental to the consumer, but is the contract in bad faith? At the moment this question must remain open.

\section{Conclusions}

The $\mathrm{C} 2 \mathrm{C}$ electronic commerce model is a new and exciting area in the relatively new field of e-commerce law. The main aim of the present paper was to open the debate in this area by taking a look at some of the questions posed by this method. More research in the field will be definitely welcome as it suffers from some lack of interest from the academic community.

Of the many interesting legal issues in the area of online auctions, the one that appears to pose more interesting problems for the law is that of the liability issues. Both existing legislation and case law do not appear to strongly indicate whether or not intermediary sites will be liable for fraudulent transactions committed in the site, further developments in this area should be closely monitored, even though there is growing consensus in providing intermediaries with indemnity from liability under certain circumstances.

As far as the analysis of the exclusion of liability clauses included in eBay's contract, the answer must also remain open. There is enough in the clause to believe that it will be found unfair if it is ever challenged in court, but until that happens the question must remain open.

\section{Bibliography}

"Ebay shuts down Columbia auctions", The Register, February 3, 2003. @ : <http://www.theregister.co.uk/content/6/29147.html>

Brunker, M. "Cautionary tales of two auctions", $M S N B C$, October 10, 2002. @: <http://www.msnbc.com/news/818257.asp?0si\&cp1=1>

Bunnell, D and Luecke, R. The eBay Phenomenon. New York : John Wiley, 2000. 
Cohen, A. "On-Line Auctions: Bidding for Bargains", New York Law Journal, January 19, 1999. @: <http://www6.law.com/ny/tech/011999t4.html>

Cohen, A. The Perfect Store: Inside eBay, Boston: Little, Brown \& Co; 2002.

Davis, C. "Court Dismisses Class Action Against eBay in Counterfeit Sports

Memorabilia Case", Internet Law Journal, March 8 2001. @:

<http://www.tilj.com/content/litigationheadline03080101.htm>

eBay. eBay Inc. Announces Third Quarter 2002 Financial Results, October 17, 2002.

@: <http://www.shareholder.com/ebay/news/20021017-92686.htm >

Festa, P. "Identity thieves strike eBay”, CNET News, November 22, 2002. @:

<http://news.com.com/2100-1017-966835.html>

FTC. Internet Fraud. Statement by the FTC to the Subcommittee on Commerce, Trade and Consumer Protection, 2000. @:

<http://www.ftc.gov/os/2001/05/internetfraudttmy.htm>

Gatt, A. "Electronic Commerce - Click-wrap agreements: The enforceability of clickwrap agreements", Computer Law \& Security Report, Vol. 18, Issue 6, November 2002, pp.404-410.

Katsh, E; Rifkin, J; and Gaitenby, A. "E-Commerce, E-Disputes, and E-Dispute Resolution: In the Shadow of 'eBay Law'", Ohio State Journal on Dispute Resolution, Vol. 15:3, 200, p.706.

Mcedrick, E. Contract Law, Fourth Edition, Basingstoke: Palgrave, 2000, pp.231-242.

National Consumers League. Online Auction Fraud Skyrocketing in 2002, August 2002, @: 〈http://www.nclnet.org/fraudweek2.htm>

Regan, K. "PayPal Users Sue over Frozen Funds". In E-Commerce Times, March 13, 2002. @: <http://www.ecommercetimes.com/perl/story/16751.html>

Rule, C. Online dispute resolution for business: B2B, e-commerce, consumer, employment, insurance, and other commercial conflicts, San Francisco: Jossey-Bass, 2002.

Selis, P; Ramasastry, A. and Sato, A. Towards a Fraud-Free Marketplace: Best Practices for the Online Auction Industry. Report by the Washington Attorney General's Office, April 2001. @:

<http://www.wa.gov/ago/consumer/auctions/home.htm>

Sutter, G. Don't Shoot the Messenger? The Evolution of Liability for third Party Provided Content in the UK, 17th BILETA Annual Conference, Free University, Amsterdam, 2002. @: 〈http://www.bileta.ac.uk/02papers/sutter.html>

Zimmermann, R. and Whittaker S. (eds) Good faith in European contract law, Cambridge: Cambridge University Press, 2000. 